\title{
Disciplining dissent: multicultural policy and the silencing of Arab- Canadians
}

\section{RAFEEF ZIADAH}

Abstract: This article examines two cases of state funding cuts to the most prominent and active Arab community organisations operating in Canada, the Canadian Arab Federation and Palestine House. It contextualises the cuts within broader 'crisis of multiculturalism' debates imbued with anti-Arab/anti-Muslim racism and the silencing of Palestine advocacy efforts; arguing that the shift to a neoliberal multiculturalism, emptied of anti-racist politics, along with the construction of national identities around a set of western 'core values' has advanced a marginalising politics that demarcates a 'civilisational' border which excludes Arabs, Muslims, and by extension Palestine solidarity. Curtailing freedom of expression, partly through funding cuts, thus becomes a key mechanism for disciplining dissent in racialised communities.

Keywords: anti-Arab racism, Arab-Canadians, Canadian Arab Federation, 'core values', Israel, official multiculturalism, Palestine House, solidarity , terrorism

Rafeef Ziadah is a postdoctoral research fellow at the University of London, SOAS. 
This is the accepted version of an article published by Sage in Race \& Class 58 issue: 4, page(s): 7-22, published version available at: https://doi.org/10.1177/0306396816686272

Accepted version downloaded from SOAS Research Online: http://eprints.soas.ac.uk/24593/

As advocacy for Palestinian rights began to make some impact in Canadian universities and trade unions, the Canadian state, was well ahead of others, to respond with a consistent, repressive 'silencing campaign'. The goal of this campaign is:

quite simply to shut down political activism and scholarly exchange that explores Palestinian experiences and/or criticizes the Israeli state. This silencing project echoes that of the Israeli state itself, which has systematically clamped down on all aspects of Palestinian life while trying to eliminate signs and memories of Palestinian existence. ${ }^{1}$

The silencing campaign included a wave of funding cuts by both the Canadian International Development Agency (CIDA) and the Citizenship and Immigration Canada (CIC) to Canada-based Non Governmental Organisations (NGOs) and community groups that were deemed pro-Palestinian. ${ }^{2}$ The Canadian Arab Federation (CAF) and Palestine House, the two leading Arab / Palestinian community organisations, funded through a Citizenship and Immigration Canada programme to deliver services to newcomers of all origins, lost their funding for their English language and newcomer settlement programs. The rationale for funding cuts included labelling the organisations' Palestine related activities and rhetoric as anti-Semitic (with a broad enough definition of anti-Semitism to encompass criticism of Israel), and reliance on racialised tropes of Arab extremism. At the same time, the violence against the Palestinian people and latter's resistance to this violence was rendered invisible and unimportant.

A close examination of the silencing campaign specifically against Arab and Muslim community organisations has wider implications for oppositional movements, especially as we see attempts by a number of governments to criminalise Palestine solidarity activism altogether. For example, the British government is attempting to 
This is the accepted version of an article published by Sage in Race \& Class 58 issue: 4, page(s): 7-22, published version available at: https://doi.org/10.1177/0306396816686272

Accepted version downloaded from SOAS Research Online: http://eprints.soas.ac.uk/24593/

'prevent town hall boycotts' through changes to local council public procurement policy and pension schemes. ${ }^{3}$ In the US, legislation attempts to exclude organisations that support the Boycott, Divestment and Sanctions campaign from public funding or contracts. ${ }^{4}$ Therefore, the Canadian experience over the last decade provides a powerful foreshadowing of processes that are now emerging in Europe and the United States.

In addition to locating the funding cuts in Canada in terms of the generalised attack on pro-Palestinian activism, the article also relates the cuts to the attack on multiculturalism internationally. ${ }^{5}$ And here it is necessary to distinguish between antiracist notions of multiculturalism, often brought about by struggles of racialised groups, and neoliberal notions of multiculturalism, which amount to 'culturalism', celebration of specific cultural tropes (dance, song, food) at the expense of broader structural inequalities, including institutionalised racism. For multiculturalism is a contested term and has shifted historically and suffered a serious backlash more recently.

This backlash against official multiculturalism in western states has entailed a new framing of national identity around a set of core western values demarcating a 'civilisational' border, which facilitates the exclusion of Arabs and Muslim, and by extension community organisations representing them. Unlike policies of the 1950 s and ' $60 \mathrm{~s}$, which demanded cultural assimilation, the new emphasis on creating 'Britishness' or 'Canadianness' is framed in terms of 'core values' which minorities must assimilate. When it comes to Arab/Muslim community organisations, the assimilation entails 
This is the accepted version of an article published by Sage in Race \& Class 58 issue: 4, page(s): 7-22, published version available at: https://doi.org/10.1177/0306396816686272

Accepted version downloaded from SOAS Research Online: http://eprints.soas.ac.uk/24593/

remaining silent about issues of foreign policy, community surveillance and racial profiling. A set of racialised discursive and administrative disciplining mechanisms, including funding cuts, is utilised against organisations refusing such assimilation.

Although there are very important differences between the European and North American debates on multicultural policy, stemming from the different types of migration to both areas, the parameters around which such debates are conducted have tended to intersect; with the backlash against multiculturalism often stressing its promotion of 'ethnic enclaves' and 'segregated communities'. Such 'integration debates' as Sivanandan has accurately pointed out are about a 'descent into assimilation, under cover of "community cohesion", with British values as the yardstick of measurement' ${ }^{6}$

Underlying the debates, calling for a different type of multiculturalism (in the Canadian case an integrative multiculturalism framed around 'core liberal values'), or repeatedly declaring its failure (in the European case), is usually an essentialised Muslim/Arab figure that is unable to integrate into western society and adapt to a new value system. Liz Fekete has intricately described the 'new popular 'common sense' racism against Muslims and foreigners' invoked in such debates on integration: 'it is a racism that builds on the proliferation of stereotypical generalisations about 'Muslim culture' and the Islamic mind-set that have been generated over the last decade. ${ }^{7}$ As Arat-Koc explained the so-called war on terror 'jettisoned those of Arab and Muslim 
This is the accepted version of an article published by Sage in Race \& Class 58 issue: 4, page(s): 7-22, published version available at: https://doi.org/10.1177/0306396816686272

Accepted version downloaded from SOAS Research Online: http://eprints.soas.ac.uk/24593/

background from their place in Western nations and "Western civilization" and made precarious the national belonging and political citizenship of many other Canadians of colour'. ${ }^{8}$ Jasmine Zine noted, 'increasingly positioned as anti-liberal, anti-democratic and unnameable to the requirements of modernity, Muslims represent the "anticitizen". . 9 Studying the categories of 'Muslim' and 'Arab', author Sherene Razack also clarified their racial marking outside of whiteness and exclusion as internal-outsiders from legal rights and civil liberties. ${ }^{10}$ This has mainly crystalised in the increased securitisation of state / community relations, the rushing through of anti-terror legislation, mainly aimed at Arabs and Muslims, and the curtailment of civil liberties. While such direct disciplining mechanisms have received a level of attention, less recognised is the more subtle censorship of activities and groups deemed outside a core set of western values.

Multicultural funding,, which encourages community organisations to become more dependent on state funding and less interested in building anti-racist solidarities across communities, is often an important disciplining mechanism. Inevitably, community groups' focus turns to survival and 'service provision' as they become more vulnerable and susceptible to the exercise of state discipline.

Methodologically, in reconstructing the narrative behind the funding cuts this paper relies on: official correspondence between the organisations and government departments; media reports, including op-ed and editorials; statements from party 
This is the accepted version of an article published by Sage in Race \& Class 58 issue: 4, page(s): 7-22, published version available at: https://doi.org/10.1177/0306396816686272

Accepted version downloaded from SOAS Research Online: http://eprints.soas.ac.uk/24593/

leaderships and key government figures; and freedom of information requests. In examining these materials, it looks at the ways in which government spokespeople justified their silencing of counter voices, focusing on the ways organisations are described and the references to Canadian 'values' as a means of buttressing repressive measures.

\section{Neoliberal multiculturalism: the Canadian case}

As a 'new approach to nation-building', Canada's official multiculturalism has been seen as ostensibly tolerant and accepting of cultural difference -- allowing the state to both manage and limit what has come to be known as Canadian diversity. ${ }^{11}$ Although Canada's multicultural policy has long been debated, today the idea of being multicultural and tolerant is deeply intertwined with the Canadian national narrative. The widely held belief that Canada represents one of the most successful models of multiculturalism in the world means that analyses of anti-Arab racism or critical accounts of Canadian foreign policy in the Middle East have been few and far between.

Examining funding of community groups in terms of Canada's official multicultural policy begins to explain the ways in which state policies have changed and how a reliance by community groups on state funds, in an economic context increasingly marked by neoliberalism, depoliticises them -- turning them into 'service provision' organisations rather than advocacy groups. Importantly, it also reveals that 
This is the accepted version of an article published by Sage in Race \& Class 58 issue: 4, page(s): 7-22, published version available at: https://doi.org/10.1177/0306396816686272

Accepted version downloaded from SOAS Research Online: http://eprints.soas.ac.uk/24593/

the state's official rhetoric of commitment to multiculturalism and diversity has not been backed with equivalent funding prioritisation. As noted by Abu-Laban and Gabriel, by the new millennium, multiculturalism was an area of 'relatively little state spending, 12

Multiculturalism as state policy in Canada began in 1971, and was further codified with the 1988 passage of the Canadian Multiculturalism Act (CMA), whereby Canada became the first country in the world to legally define multiculturalism. Canada's multicultural policy has been marked by a high degree of fluidity. In the 1970s, it was framed as 'ethnic multiculturalism,' and focused on the maintenance of identities, folklore, and language training. In the 1980s, after coming under criticism for the failure to deal with issues of institutional racism, multicultural policy objectives shifted to integrate issues of equity in Canadian society. In the 1990s, multicultural programmes were once again reframed, and an emphasis on integration and civic participation was introduced. By 2009, three new objectives for the Multiculturalism Program were approved and came into effect on April 1, 2010: to build an integrated, socially cohesive society; to improve the responsiveness of institutions to meet the needs of a diverse population; and to actively engage in discussions on multiculturalism and diversity at an international level. ${ }^{13}$

The primary governmental unit for dealing with multicultural policy also changed over the years. Originally entrusted to the Multicultural Directorate created for 
This is the accepted version of an article published by Sage in Race \& Class 58 issue: 4, page(s): 7-22, published version available at: https://doi.org/10.1177/0306396816686272

Accepted version downloaded from SOAS Research Online: http://eprints.soas.ac.uk/24593/

this purpose within the Department of the Secretary of State, the implementation of the policy was moved to the new Department of Multiculturalism and Citizenship in 1991. The new Department was in turn dismantled in 1993 and the multiculturalism programmes transferred to a new Canadian Heritage Department. Finally, in 2008, responsibility for administering the Canadian Multiculturalism Act moved from the Department of Canadian Heritage to Citizenship and Immigration Canada (CIC).

Representing a culmination of over a decade of growing dominance of neoliberal ideas of governance, a key moment of transition in the practices of funding multiculturalism took place in 1995, when the federal Liberals commissioned Brighton Research, a private company, to evaluate the multiculturalism programme. One of the pivotal recommendations of its report was on funding, noting that 'past funding practices have reinforced the impression that multiculturalism is a programme of special interests'. ${ }^{14}$ In the subsequent three years, the programme was redesigned in line with the report's recommendations, so that funding would be provided on a project by project basis. Less money was therefore available to fund the general and autonomous operations of community groups. Ethnocultural communities were still eligible for funding, but they had to address the new objectives and compete with private entities when applying for funding. Organisations applying for funds had to craft each project to meet funding criteria, thus losing a measure of autonomy and forced to focus on 'servicing clients.' 
This is the accepted version of an article published by Sage in Race \& Class 58 issue: 4, page(s): 7-22, published version available at: https://doi.org/10.1177/0306396816686272

Accepted version downloaded from SOAS Research Online: http://eprints.soas.ac.uk/24593/

By 1998, the programme's objectives focused less on preserving cultural identity and working with community groups dedicated to single communities; instead, the goal was to 'inculcate an attachment to Canada (as opposed to cultural maintenance) and to create active citizens'. ${ }^{15}$ Ethnocultural organisations did not support this shift at the time. In fact, the Canadian Ethnocultural Council criticised the shift, arguing that community groups were not consulted, and that the Brighton Report failed to address the issue of ongoing funding cuts to multicultural programming to begin with. ${ }^{16}$

Two shifts occurred simultaneously to the multiculturalism programme. First, it suffered decreased funding and was opened up to the market to create competition over grants, and was thus made both more vulnerable to and more dependent on governmental arbitrariness. Second, the purpose of the programme itself was 'increasingly emphasised as a way to deal with global markets and global competitiveness'. ${ }^{17}$ Thus the objectives of the multiculturalism program, as well as its funding, were transformed in line with neoliberal precepts of restructuring state/community relations, emphasising efficiency in 'service delivery, and the purpose subordinated to the discourses of neoliberal globalisation.

Following the electoral victory of the Conservative Party in 2006, a new policy review of the programme was conducted in 2007. It recommended adjusting multiculturalism programming to focus more on integration and linking the programme to broader notions of citizenship and Canadian identity. The minister responsible for the 
This is the accepted version of an article published by Sage in Race \& Class 58 issue: 4, page(s): 7-22, published version available at: https://doi.org/10.1177/0306396816686272

Accepted version downloaded from SOAS Research Online: http://eprints.soas.ac.uk/24593/

portfolio, Jason Kenney, explained that this 'allow[ed] for greater coordination between the government's settlement programs for newcomers and its programs to promote further inclusion, participation and shared citizenship for all Canadians' ${ }^{18}$ Kenney, as detailed below, would go on to play a central part in authorising the funding cuts to CAF and Palestine House. In a speech titled 'Good Citizenship: The Duty to Integrate', he explained,

our immigration program, our citizenship program, our multiculturalism program must increasingly focus on integration, on the successful and rapid integration of newcomers to Canadian society, and on a deepening understanding of the values, symbols and institutions that are rooted in our history, not just for newcomers but for all Canadians. ${ }^{19}$

The objectives of the programme were updated even further in 2009 , with a focus in the direction of inculcating a Canadian identity based on, among other things 'promoting intercultural understanding, fostering citizenship, civic memory and pride, and respect for core democratic values, and promoting equal opportunity for individuals of all origins'. ${ }^{20}$

The three major funding streams involving newcomers and multiculturalism were: Settlement, Resettlement, and Inter-Action. Outcomes for the Settlement program were stated as Orientation to Newcomers, Language/Skills, Labour Market Access, welcoming communities, and finally, Policy and Program Development. ${ }^{21}$ The InterAction stream was conceived as 'Canada's Multiculturalism Grants and Contribution Program' with the objectives of intercultural/interfaith understanding, civic memory and 
This is the accepted version of an article published by Sage in Race \& Class 58 issue: 4, page(s): 7-22, published version available at: https://doi.org/10.1177/0306396816686272

Accepted version downloaded from SOAS Research Online: http://eprints.soas.ac.uk/24593/

pride, and respect for core democratic values. ${ }^{22}$ This constituted an ever-clearer connection between fostering a unified Canadian identity based on the idea of a set of 'core values' that belonging to the nation necessitated. Such core values were attributed to a specifically western tradition. In the 2009 speech, Kenney noted that there must be a focus 'on the political values that are grounded in our history, the values of liberal democracy rooted in British Parliamentary democracy that precisely have given us the space to accommodate such diversity.'

This shift towards a more integrative multiculturalism, anchored in the discourse of core values, coincided with other reorientations of Canadian policy, including a shift of foreign policy towards greater alignment with the US and the war on terror. Arun Kundnani argues that a similar process took place in Britain as well:

[the] new conventional wisdom is that a national story of Britishness must be promoted in order to bind the nation together around a set of core values, to which minorities must assimilate. This integrationism draws on a wider antiMuslim political culture associated with the 'war on terror', in which the focus is on 'self-segregation', alien values and forced assimilation, rather than on institutional racism. ${ }^{23}$

The idea of common values between Canada and Israel also increased in popularity among Canadian politicians, and was fundamental to the new ideological construction of the relationship between the two states. Thus, the reorientation of citizenship and belonging around 'values' had significance in transforming international alliances and the repositioning of Canada in a 'civilisational' camp.

One of the avenues in which this articulation of citizenship was presented was 
This is the accepted version of an article published by Sage in Race \& Class 58 issue: 4, page(s): 7-22, published version available at: https://doi.org/10.1177/0306396816686272

Accepted version downloaded from SOAS Research Online: http://eprints.soas.ac.uk/24593/

the Citizenship and Immigration Canada guide for the citizenship test, titled Discover Canada: The Rights and Responsibilities of Citizenship. Interestingly, the first letter to Palestine House notifying the organisation of a funding review, dated 16 December, 2011, referenced the guide and noted: 'as stated in CIC's guide to new Canadians 'some Canadians immigrate from places where they have experienced warfare or conflict. Such experiences do not justify bringing to Canada violent, extreme or hateful prejudice. ${ }^{24}$ The use of the guide is significant: it was utilised for managing what experiences the immigrant can and cannot 'bring' into Canada.

According to a CIC report evaluating the multiculturalism programme, the updated guide 'strengthens the content on common Canadian values such as freedom, democracy, human rights, the rule of law and the equality of men and women'. ${ }^{25}$ Moreover, right after the guide was reissued, 'an advertisement campaign on citizenship was launched which emphasised the meaning of being Canadian and the importance of Canada's values, symbols, institutions and history'. ${ }^{26}$ The use of the guide in the context of a letter issued to review organisational funding underlines the use of such seemingly benign guides in disciplining communities.

\section{Defunding the Canadian Arab Federation}

Arab community organisations were historically organised through the Canadian Arab Federation (CAF), and the Palestinian community was specifically involved with the Palestine House Educational and Cultural Centre (which is a member group of CAF). 
This is the accepted version of an article published by Sage in Race \& Class 58 issue: 4, page(s): 7-22, published version available at: https://doi.org/10.1177/0306396816686272

Accepted version downloaded from SOAS Research Online: http://eprints.soas.ac.uk/24593/

Both organisations lost their funding for Settlement and English training programmes from CIC. The stated reason for the funding cuts to CAF was the perception that the organisation's leadership was anti-Semitic and supported extremism. As for Palestine House, the organisation received a letter explaining that it was losing funding because of actions 'that could arguably be seen as extreme'. ${ }^{27}$ The following section traces the history and reasoning for those funding cuts, addressing the way both organisations were stigmatised and disciplined by the state for their opposition to its uncritical support for Israel, and for addressing the increased racial profiling and targeting of ArabCanadians.

CAF was formed in 1967 as a direct response to the 1967 Israeli occupation of the West Bank and Gaza Strip. It was decided by members of the Arab community that there was an urgent need to mobilise, no matter where their place of residence, and present a united voice to advocate for Arab-Canadians. CAF was envisaged as a vehicle for Arab-Canadians to voice their opinions on the politics of the region they came from and to influence policies in the new state they lived in, challenging the negative stereotypes of Arabs in Canada. At the time, Arab nationalism was strong among the newcomer community and the number of Arab-Canadians was small, so it made sense politically and logistically to unite under the banner of one organisation.

As early as 1982, CAF commissioned a study about racial stereotypes of Arabs in political cartoons published in Canadian newspapers, where Arabs were repeatedly 
This is the accepted version of an article published by Sage in Race \& Class 58 issue: 4, page(s): 7-22, published version available at: https://doi.org/10.1177/0306396816686272

Accepted version downloaded from SOAS Research Online: http://eprints.soas.ac.uk/24593/

portrayed as terrorists. The researcher pointed to the danger of such pervasive negative imagery, recalling the role played by German caricaturists in their similar depictions of Jews as laying the groundwork for the Holocaust. ${ }^{28}$ During the war against Iraq, after the invasion of Kuwait, CAF documented over 100 violent anti-Arab incidents across Canada. $^{29}$

With the continuing migration of Arabs to Canada, with many fleeing wars or repressive regimes, and with the weakening of Arab nationalist sentiment in the Middle East, Arab newcomers began to retreat into national- or sectarian-based organisations, and CAF became an umbrella for those smaller groups (by 2010, CAF stated that its membership consisted of forty Arab-Canadian community groups). CAF's aims included influencing Canadian public policy in matters related to the Middle East, and raising issues of civil liberties, racial profiling, and racism affecting Arab-Canadians.

With the restrictions on multicultural funding, CAF began to also run government-funded programs, such as Job Search Workshops aimed at assisting new immigrants in learning skills like resume and cover letter writing. CAF also ran a LINC Program (Language Instruction for Newcomers to Canada) for eleven years with funding provided by Citizenship \& Immigration Canada (CIC); in 2008, CIC approved the continuation of the program's contract for 2009-2010.

After September 11, when racial profiling of Arab-Canadians and Muslims increased, CAF was heavily involved in organising a response to new legislation that 
This is the accepted version of an article published by Sage in Race \& Class 58 issue: 4, page(s): 7-22, published version available at: https://doi.org/10.1177/0306396816686272

Accepted version downloaded from SOAS Research Online: http://eprints.soas.ac.uk/24593/

enhanced the targeting of Canadians of Arab origin, such as the Immigration and Refugee Protection Act of June 2002, and the Anti-Terrorism Act, introduced in October 2001. In a position paper to CIC, published in April 2003, CAF warned of the sweeping new anti-terror regulations, explaining that such measures after 'September the 11th and its aftermath have left Arab and Muslim Canadians reeling with sentiments of anxiety, fear, alienation, marginalization, betrayal, and disillusionment ${ }^{30}$ However, the language used by CAF sought to strike a balance between civil liberties and the security concerns of the state. For example, in 2005, CAF president Omar Alghabra (later to become a Member of Parliament for the Liberal Party of Canada) stated in the CAF Annual Report that it was 'working hard to advance a Canada that is inclusive of diversity and respectful of the balance required to protect both security and civil liberties'. ${ }^{31}$ Earlier in April 2003, CAF's position statement on multiculturalism and civil rights argued that:

given that multiculturalism is premised on the equal treatment and respect of all citizens, Canada needs to consider how the security agenda and multiculturalism can co-exist. To date, the former has come at the expense of the latter . . . we need to determine, as a society, how to combine our desire to respect human rights and multiculturalism with our need to protect our security and trade interests. $^{32}$

With security becoming the dominant theme of Canadian politics, and with the rightward shift in Canadian foreign policy towards overt support for US policy objectives in the Middle East, CAF's straddling strategy became increasingly untenable. Under the new presidency of Khaled Mouammar, CAF's political rhetoric shifted to a 
This is the accepted version of an article published by Sage in Race \& Class 58 issue: 4, page(s): 7-22, published version available at: https://doi.org/10.1177/0306396816686272

Accepted version downloaded from SOAS Research Online: http://eprints.soas.ac.uk/24593/

more active condemnation of Canadian foreign policy and toward explicit support for Palestinian and anti-war solidarity actions and groups, such as the Coalition Against Israeli Apartheid and the Toronto Coalition to Stop the War. On the one hand, the newly elected Conservative government leadership was not meeting with CAF, such courtesy meetings had at least existed with previous governments. CAF itself, largely in response to events in the Middle East, was becoming increasingly alienated and taking public positions condemning the shift in both foreign and domestic policies related to Arabs and Palestinians. This coincided with the emergence of a stronger grassroots movement in support of Palestinian human rights across campuses in Canada, a development that emboldened CAF and led it to take a more active role at the grassroots level-versus the lobbying model which no longer seemed to yield results on the political front. This shift alienated some of CAF's traditional base organisations invested in keeping open lines of communication with political parties, and in keeping and securing more funding for the services they provided through CIC grants.

But the disjuncture between the Canadian government and CAF became particularly marked in the summer of 2006, when Israel attacked Lebanon. While CAF helped to organise demonstrations against the war and mobilised the Arab-Canadian community, the Harper government's response was one of overt support for Israel. By 2006, then, the leadership of CAF was explicitly making the connections between ongoing wars in the Middle East and domestic policies affecting Arab Canadians. 
This is the accepted version of an article published by Sage in Race \& Class 58 issue: 4, page(s): 7-22, published version available at: https://doi.org/10.1177/0306396816686272

Accepted version downloaded from SOAS Research Online: http://eprints.soas.ac.uk/24593/

It was in February 2009 that minister Kenney announced that he would review the federal funding to CAF for its settlement services. It is very telling that he made this announcement at a conference against the 'new anti-Semitism' in London, UK on February 18, 2009:

These [Canadian Islamic Congress (CIC) and CAF] and other organisations are free within the confines of our law and consistent with our traditions of freedom of expression, to speak their mind, but they should not expect to receive resources from the state, support from taxpayers or any other form of official respect from the government or the organs of our State [emphasis added]. And I would encourage all other governments to take a similar approach to organisations that either excuse violence against Jews or express essentially antiSemitic sentiments. ${ }^{33}$

Here, Kenney was articulating the view that governmental funding could be made contingent on recipients' political views. This happened soon after Khaled Mouammar, during a rally against the bombing of Gaza that year, had called Kenney (and other Canadian politicians) 'professional whores' for their support of Israel. Kenney explicitly identifies the anti-war organising of CAF with anti-Semitism, altering the definition of anti-Semitism itself. Any legitimate criticism of the Canadian state's overt support and justification during Israel's military assault on Lebanon in 2006 and later on Gaza in 2008/9, which killed hundreds of people and destroyed entire neighbourhoods, was thus dismissed.

At the time, CAF's member organisations issued a statement supporting CAF President Khaled Mouammar, but did add that Mouammar's use of the term 'professional whore' was 'unfortunate'. The groups were attempting damage control at 
This is the accepted version of an article published by Sage in Race \& Class 58 issue: 4, page(s): 7-22, published version available at: https://doi.org/10.1177/0306396816686272

Accepted version downloaded from SOAS Research Online: http://eprints.soas.ac.uk/24593/

this point, but that did not help. Divisions among the groups were accentuated however; as, internally, groups argued that the CAF leadership approach was alienating the Arab community from the mainstream Canadian political establishment. While there was broad support for the CAF leadership at the grassroots level, especially in the student movement, the more established sections of the community were starting to make their opposition heard and argue that they would have to disaffiliate from CAF to save their reputations.

On March 18, 2009, Rick Stewart, then Associate Assistant Deputy minister, Operations at CIC, wrote to CAF that the government would not renew a two-year, $\$ 2.1$ million contract, which expired that month, for immigrant language instruction that CAF provided. A second $\$ 473,873$ contract for immigrant job search assistance was also threatened. Stewart's letter included a statement from minister Kenney justifying the decision to halt funding. It is worth quoting at length:

Serious concerns have arisen with respect to certain public statements that have been made by yourself or other officials of the CAF. These statements have included the promotion of hatred, anti-Semitism and support for the banned terrorist organisations Hamas and Hezbollah. The objectionable nature of these public statements in that they appear to reflect the CAF's evident support for terrorist organisations and positions on its part which are arguably anti-Semitic raises serious questions about the integrity of your organisation and has undermined the government's confidence in the CAF as an appropriate partner for the delivery of settlement services to newcomers. ${ }^{34}$

Interestingly, the letter uses terms such as 'they appear to reflect' and 'arguably antiSemitic' -- vague terms that avoid any legal terminology, reference to hate-crimes, or 
This is the accepted version of an article published by Sage in Race \& Class 58 issue: 4, page(s): 7-22, published version available at: https://doi.org/10.1177/0306396816686272

Accepted version downloaded from SOAS Research Online: http://eprints.soas.ac.uk/24593/

reference to anti-terror legislation. In other words, the statement is based on the perceptions and biases of the minister in charge, not on any formal investigation that CAF was given a right to respond to. The use of terms such as 'terrorist' and 'antiSemitism' provided a context in which even liberal notions of due process and impartiality could simply be ignored. This is a common mechanism used throughout cases of censorship against Palestine solidarity outside Canada as well.

In the legal proceedings that followed CAF's application to the federal court for an interim injunction, the court did find that minister Kenney may have breached his legal duty to act fairly towards CAF. Justice Kelen, who presided over the case, made it clear that it would be inappropriate for the minister to cut CAF's funding because its President had called the minister a name, stating:

Being a target of public criticism is part of holding public office. If the minister decided to cancel the English as a Second Language funding contract for the Canadian Arab community simply because he was called a name . . . his decision should not stand. It was not unexpected that the Arab community would be repulsed by Israel's invasion of Gaza . . . the Arab community was upset that the Canadian government did not strongly protest this attack. Many reputable Canadian Jews were similarly opposed to [the] attack. ${ }^{35}$

In its decision, the court stated that the minister was legally obligated to advise CAF of his reasons for intending to cancel the contract, to provide CAF with a full opportunity to respond, and to fairly take into account this response before making his final decision. Minister Kenney took only the procedural lesson to heart; as will be explained below, for later funding cuts to Palestine House, he sent a letter warning that 
This is the accepted version of an article published by Sage in Race \& Class 58 issue: 4, page(s): 7-22, published version available at: https://doi.org/10.1177/0306396816686272

Accepted version downloaded from SOAS Research Online: http://eprints.soas.ac.uk/24593/

he was investigating the organisation, requested a response, and later proceeded to cut the funding.

\section{Palestine House}

The Palestine House Educational and Cultural Centre suffered a similar fate to the Canadian Arab Federation in 2012. Palestine House is a not-for-profit organisation that was established in June 1992 through the joint efforts of various Palestinian associations in Canada. It serves as the educational, cultural, and social centre for the Palestinian community. On December 16, 2011, in response to an application to renew its CIC funding, the organisation received a letter signed by Kenney, notifying it of a review. The letter noted that the settlement programme was not only for language training, 'it also facilitates the settlement and social, cultural, economic and civic integration of sometimes vulnerable and impressionable immigrants and refugees into Canadian Society.' The letter also stated, 'we expect that a service provider will conduct itself in a manner that could not be perceived as extreme or endorsing violence against any person or group,' adding that the review will take into account actions, statements, and positions that 'may be incompatible with CIC's interest in providing services to new Canadians, free of any association with extreme political activity or views'. ${ }^{36}$ The letter did not specify how the review would be conducted, or importantly, what constituted ‘extreme' activity and political views.

The letter went on to stress three actions that the ministry found objectionable, 
This is the accepted version of an article published by Sage in Race \& Class 58 issue: 4, page(s): 7-22, published version available at: https://doi.org/10.1177/0306396816686272

Accepted version downloaded from SOAS Research Online: http://eprints.soas.ac.uk/24593/

explaining that 'Palestine House has a history of taking positions that could be interpreted as extreme or supportive of terrorists and terrorism and viewed as offensive to newcomers and to many Canadians' ${ }^{37}$ The incidents cited in the letter as objectionable included: 'the presence on your [Palestine House] website of a map showing a Palestinian state encompassing all of Israel.' A Palestine House event held on Oct 8,2011 , marking the release by Israel of about 1,000 prisoners in an exchange deal with Hamas for the abducted Israeli soldier Gilad Shalit, was also cited, with the letter stating that the freed prisoners were "convicted terrorists and at least one individual who murdered two Canadian citizens.' Lastly, a March 2010 event was cited, for which the Palestine House hosted Abdul Bari Atwan, a journalist based in London, for Palestinian Land Day commemorations, which the centre hosts yearly. The letter specifically quoted Atwan's comment from a televised interview on a Lebanese channel, where he said: 'If the Iranian missiles strike Israel, by Allah, I will go to Trafalgar Square and dance with delight.'

Palestine House responded by explaining that the map on the website was merely an outline of historical Palestine, a geography that many Palestinian-Canadians continue to be connected to, adding that it could be easily removed. On the subject of the event to mark the release of Palestinian prisoners, Palestine House explained that the event was in support of the prisoners and all their families, not one particular prisoner, adding that the majority of Palestinians are tried under Israeli military courts for 
This is the accepted version of an article published by Sage in Race \& Class 58 issue: 4, page(s): 7-22, published version available at: https://doi.org/10.1177/0306396816686272

Accepted version downloaded from SOAS Research Online: http://eprints.soas.ac.uk/24593/

political activities of any kind. On the final issue of hosting Abdul Bari Atwan, the organisation made clear that he was hosted as a prominent London-based Palestinian journalist with a long career, and that it was not aware of the particular statement quoted and in any case did not agree with it.

The response did not convince the Ministry, and in January 2012, the Palestine House was informed that the CIC would not enter into a new agreement with them. Twenty staff members lost their jobs due to these cuts, the majority of them both women and non-Palestinian. Most individuals receiving services from the centre were of Chinese and South Asian background, and were neither Arab nor Palestinian.

In both of the above cases, CAF and Palestine House were not assessed on their programme delivery (in fact both had received high ranking for this). Rather, the judgment was on their positions, actions, and events regarding Canadian foreign policies, and specifically their criticism of Israeli state policies. One of the arguments on the state side was that state funding should not go towards advocacy activities. However, funds given by the state through CIC for settlement programmes are monitored very closely through monthly reports that managers must submit to CIC; these reports are detailed to the point of recording exact spending on photocopying, office supplies, and so on. Both CAF and Palestine House insisted that none of their activities that were Palestine-related were ever supported with CIC funds. This indicates that the issue for the government was not the manner in which the funding was used (as 
This is the accepted version of an article published by Sage in Race \& Class 58 issue: 4, page(s): 7-22, published version available at: https://doi.org/10.1177/0306396816686272

Accepted version downloaded from SOAS Research Online: http://eprints.soas.ac.uk/24593/

the monthly reports they received easily proved the effective organisational operations in using the resources) but a case of specifically disciplining groups for their activities unrelated to 'service delivery'. It is unclear, however, what positions on Palestine CIC would deem acceptable within the norms of 'tolerable' speech and the confines of official multiculturalism.

While the above-mentioned funding cuts happened under the Conservative government, politicians from Canada's Liberal Party have been supportive and involved in the silencing campaign. In the run up to his successful 2015 election victory, the current Liberal Prime Minister, Justin Trudeau, tweeted 'The BDS movement, like Israeli Apartheid Week, has no place on Canadian campuses'. ${ }^{38}$ And it was Paul Martin, a Liberal prime minister, who first explained the relationship between Canada and Israel in terms of shared values. With very few exceptions, the Canadian political establishment is devoutly pro-Israel (and makes no effort to hide this), yet there is hardly space for Arab-Canadians to challenge this status quo.Therefore, the acquiescence of Arab-Canadian community organisations is necessary for Canadian foreign policy imperatives. For all the rhetoric about celebrating diversity and the importance of multiculturalism to Canadian identity, the limits of tolerance within an integrative multiculturalism formed around 'core values' are clear when it comes to oppositional political views.

\section{Conclusion}


This is the accepted version of an article published by Sage in Race \& Class 58 issue: 4, page(s): 7-22, published version available at: https://doi.org/10.1177/0306396816686272

Accepted version downloaded from SOAS Research Online: http://eprints.soas.ac.uk/24593/

Arabs and Muslims have come to understand that 'integration debates' reduce their communities into extremists and moderates, and that the main role of a citizen in such a circumstance is to prove at all times that s/he belongs to the latter. However, as Thobani explains, 'unfortunately for the good Muslims, no matter how deep their gratitude to the nation, no matter how ardent their embrace of western civilizational norms, the new anti-terrorism measures continue to make them as equally suspect as the bad Muslims'. ${ }^{39}$ Palestinian and Palestine solidarity groups more specifically find themselves marginalised and silenced through an ongoing process that brands them as 'extreme' and 'outside the norms of civility', with 'civility' offering 'an ideological marker of those contrasting themselves as civil from those they take to deny the condition, or even its possibility'. ${ }^{40}$

Both CAF and Palestine House were doomed to fit the category of 'bad Muslim' despite all attempts to escape this label. The securitisation of state/community relations increases levels of state censorship against community groups propagating oppositional views. The neoliberal tactic of subjecting the funding of community organisations to market incentives further increases the vulnerability of community groups and strengthens the state's power to discipline them. In an atmosphere of decreasing funding, with the language of 'homegrown terrorism and domestic threats,' commonplace, self-imposed censorship becomes a key method of survival. On the other hand, state silencing campaigns rarely stop at the boundaries of single communities, 
This is the accepted version of an article published by Sage in Race \& Class 58 issue: 4, page(s): 7-22, published version available at: https://doi.org/10.1177/0306396816686272

Accepted version downloaded from SOAS Research Online: http://eprints.soas.ac.uk/24593/

eventually dynamics of racialisation and inferiorisation spill out to encompass all dissent against state policies.

Both CAF and Palestine House continue to operate without government funding, but in many ways the funding cuts had the intended outcome of curtailing dissent by setting these cases as examples to warn off others. The cuts to funding also acted to effectively polarise community organisations between those who would stand up publicly against government policy and those preferring to work within the political space allotted by the government. The court case for CAF took up much of the organisation's resources and the group decided not to appeal the court decision for lack of resources, while the government side was able to stall and delay proceedings.

Under current circumstances of increasing scrutiny and criminalisation of Palestine solidarity internationally, it is crucial to ask, as Kundnani does in the UK case: 'is there, then, any basis for overcoming the legacy of communal identity politics through building new alliances, not in the sense of paper coalitions but at the level of genuine solidarities rooted in community-based activism? ${ }^{41}$ Such coalition building would have to centrally address the manifestations of anti-Arab, anti-Muslim racism and to seriously tackle the issue of sustainable grassroots organising outside state funding structures.

With the rise of increasingly exclusionary nationalisms, discussions on multiculturalism and anti-racist alliances are urgently needed beyond a binary of for or 
This is the accepted version of an article published by Sage in Race \& Class 58 issue: 4, page(s): 7-22, published version available at: https://doi.org/10.1177/0306396816686272

Accepted version downloaded from SOAS Research Online: http://eprints.soas.ac.uk/24593/

against multiculturalism. A multiculturalism not embedded within anti-racist politics

can amount to a neoliberal celebration of marketable diversity at the expense of social and economic justice. It is not merely a 'recognition' and 'tolerance' that the state can dictate, manipulate, fund and sanction that will resolve issue of institutionalised racism. Without substantively addressing relations of power, especially the ways in which exclusion and silencing operate, the dominant framing of national identity in western states around core values will continue to act as a veil for the status quo, condemning those outside the mainstream to a position of permanent marginalisation.

\section{References}

\footnotetext{
${ }^{1}$ M. Nadeau \& A Sears, 'This is what complicity looks like: Palestine and the silencing campaign on campus'The Bullet - Socialist Project, E Bulletin No. 475 (5 May 2011), available at: http://www.socialistproject.ca/bullet/475.pdf

${ }^{2}$ Kairos Canada, a church-based development NGO, for example, lost CDN\$7.1 million in funding from the Canadian International Development Agency (CIDA). The official stated reason was that Kairos did not fit CIDA development priorities. However, it soon emerged that the real reason was its perceived support for Palestine advocacy initiatives. $^{2}$ In December 2009, Alternatives, another NGO critical of Israel's occupation of Palestine, lost CDN\$2.1 million in CIDA funding. See'Kairos Responds to Accusations of Anti-Semitism and Renews Call for CIDA Funding to Be Restored' (18 December 2009), available at: http://www.kairoscanada.org/kairos-responds-toaccusations-of-anti-semitism-and-renews-call-for-cida-funding-to-be-restored and A. Neve, 'Voices: The campaign against advocacy and dissent deepens.' Voices-Voix. (11 May 2012), available at: http://voices-voix.ca/en/document/voices-campaign-againstadvocacy-and-dissent-deepens
} 
This is the accepted version of an article published by Sage in Race \& Class 58 issue: 4, page(s): 7-22, published version available at: https://doi.org/10.1177/0306396816686272

Accepted version downloaded from SOAS Research Online: http://eprints.soas.ac.uk/24593/

${ }^{3}$ UK Government, 'Putting a stop to public procurement boycotts'(17 February 2016), available at: https://www.gov.uk/government/news/putting-a-stop-to-publicprocurement-boycotts

${ }^{4}$ J. Ruebner, 'Congress encouraging US states to "combat BDS"' Electronic Intifada (12 February 2016), available at: https://electronicintifada.net/blogs/joshruebner/congress-encouraging-us-states-combat-bds

${ }^{5}$ On the narratives of such debates see Lentin, A. and Titley, G, The crisis of 'multiculturalism' in Europe: Mediated minarets, intolerable subjects. European Journal of Cultural Studies, (2012) 15(2), pp.123-138.

${ }^{6}$ See A. Sivanandan preface to Liz Fekete. 'Integration, Islamophobia and civil rights in Europe'Insititue of Race Relations (2008), available at:

http://www.irr.org.uk/publications/issues/integration-islamophobia-and-civil-rights-ineurope/

${ }^{7}$ See L. Fekete. 'Understanding the European-wide assault on multiculturalism. Institue of Race Relations (21 April 2011), available at:

http://www.irr.org.uk/news/understanding-the-european-wide-assault-onmulticulturalism/

${ }^{8}$ S. Arat-Koc, 'The disciplinary boundaries of Canadian identity after September 11',Social Justice, no. 32 (2005): pp. 36.

${ }^{9}$ J. Zine. Special feature article: Unsettling the nation: Gender, race and muslim cultural politics in Canada. Studies in Ethnicity and Nationalism, 20099 (1), p. 148.

${ }^{10}$ S. Razack. Casting out: The eviction of Muslims from western law and politics. (Toronto: University of Toronto Press, 2008).

${ }^{11}$ Y. Abu-Laban\&C. Gabriel, Selling diversity: Immigration, multiculturalism, employment equity, and globalization (Toronto: University of Toronto Press, 2002), p. 105.

${ }^{12}$ Y. Abu-Laban\&C. Gabriel, Selling diversity: Immigration, multiculturalism, employment equity, and globalization (Toronto: University of Toronto Press, 2002), p. 110. 
${ }^{13}$ Fleras and Kunz describe this evolution as a transition from Ethnic Multiculturalism in the 1970s, Equity Multiculturalism in the 1980s, Civil Multiculturalism in the 1990s, to Integrative Multiculturalism in the 2000s. See A. Fleras \&J. Kunz, Media and Minorities: Representing Diversity in a Multicultural Canada (Toronto: Thompson Educational Publishing, 2001).

${ }^{14}$ Department of Canadian Heritage. Strategic evaluation of multicultural programs: Final report. (Ottawa: Brighton Research, 1996), p. 76.

${ }^{15}$ Y. Abu-Laban\&C. Gabriel, Selling diversity: Immigration, multiculturalism, employment equity, and globalization (Toronto: University of Toronto Press, 2002), p. 114

${ }^{16}$ B. S. Kordan, 'Multiculturalism, citizenship and the Canadian nation: a critique of the proposed design for program renewal [Brighton Report]', Canadian Ethnic Studies, no. 29 (1997): pp 136-143.

${ }^{17}$ Y. Abu-Laban\&C. Gabriel, Selling diversity: Immigration, multiculturalism, employment equity, and globalization (Toronto: University of Toronto Press, 2002), p. 116

${ }^{18}$ J. Kenney, 'Annual report on the operation of the Canadian multiculturalism act 2007-2008' Citizenship and Immigration Canada (2009), available at: http://www.cic.gc.ca/english/resources/publications/multi-report2008/ foreword.asp

${ }^{19}$ Speaking notes for the honourable Jason Kenney, P.C., M.P. minister of citizenship, immigration and multiculturalism. 'Good citizenship: The duty to integrate.' Huron University College's Canadian Leaders Speakers' Series (March 18 2009). Citizenship and Immigration Canada. Retrieved from

http://www.cic.gc.ca/english/department/media/speeches/2009/2009-03-18.asp

${ }^{20}$ Citizenship and Immigration Canada. 'Strategic outcomes and program alignment architecture' (2012), available at: http://www.cic.gc.ca/english/department/ paa/2012/activity-33.asp

${ }^{21}$ Citizenship and Immigration Canada. 'Strategic outcomes and program alignment architecture' (2012), available at: http://www.cic.gc.ca/english/department/ paa/2012/activity-33.asp 
${ }^{22}$ Citizenship and Immigration Canada. 'Evaluation of the multiculturalism program' (2012), available at:

http://www.cic.gc.ca/english/resources/evaluation/multi/section1.asp

${ }^{23}$ A Kundnani, The end of tolerance? Racism in $21^{\text {st }}$ century Britain (London, Pluto, 2007) p. 25.

${ }^{24}$ Letter obtained by author from Palestine House.

${ }^{25}$ Citizenship and Immigration Canada. 'Annual report on the operation of the Canadian multiculturalism act 2010-2011: Part 3: The multiculturalism program 2010-2011.' (2012), available at: http://www.cic.gc.ca/english/resources/publications/multireport2011/part3.asp

${ }^{26}$ Citizenship and Immigration Canada. 'Annual report on the operation of the Canadian multiculturalism act 2010-2011: Part 3: The multiculturalism program 2010-2011.' (2012), available at: http://www.cic.gc.ca/english/resources/publications/multireport2011/part3.asp

${ }^{27}$ Letter obtained by author from Palestine House.

${ }^{28}$ F. Henry\&C. Tator, Discourses of Domination: Racial Bias in the Canadian EnglishLanguage Press (Toronto: University of Toronto Press, 2002), p. 42.

${ }^{29}$ A. Antliff,Only a beginning: An anarchist anthology (Vancouver: Arsenal Pulp Press, 2004),p.132.

${ }^{30}$ Canadian Arab Federation, 'Multiculturalism and Civil Rights' (1 April 2003), available at: http://www.caf.ca/2003/04/multiculturalism-and-civil-rights/

${ }^{31}$ Canadian Arab Federation Annual Report (2005) p. 1. Obtained by author from CAF.

${ }^{32}$ Canadian Arab Federation, 'Multiculturalism and Civil Rights' (1 April 2003)available at: http://www.caf.ca/2003/04/multiculturalism-and-civil-rights/

${ }^{33}$ CBC News. 'Kenney says some Canadian Arab groups express hatred toward Jews' (17 February 2009), available at: http://www.cbc.ca/news/ canada/story/2009/02/17/kenney-racism.html 
This is the accepted version of an article published by Sage in Race \& Class 58 issue: 4, page(s): 7-22, published version available at: https://doi.org/10.1177/0306396816686272

Accepted version downloaded from SOAS Research Online: http://eprints.soas.ac.uk/24593/

${ }^{34}$ National Post. 'Government cuts off Arab federation funding' The National Post(19 March 2009), available at: http://web.archive.org/web/20091229030918/

http://www.nationalpost.com/news/story.html?id=1406222

${ }^{35}$ Canadian Arab Federation (CAF) v. The minister of Citizenship and Immigration, 2009, para. 31. Court decision obtained by author from CAF.

${ }^{36}$ Palestine House letter, viewed by author, March 15, 2012.

${ }^{37}$ Palestine House letter, viewed by author, March 15, 2012.

${ }^{38}$ A.Abunimah, 'Canadian students reject Justin Trudeau's attack on Palestine activism, free speech’ Electronic Intifada (15 March 2015), available at:

https://electronicintifada.net/blogs/ali-abunimah/canadian-students-reject-justintrudeaus-attack-palestine-activism-free-speech

${ }^{39}$ S. Thobani, S. Exalted subjects: Studies in the making of race and nation in Canada(Toronto: Toronto University Press, 2007),p. 238

${ }^{40}$ T Goldberg, 'Racial palestinianization', in R. Lentin (ed.) Thinking Palestine (London, New York: Zed Books, 2008) p36.

${ }^{41}$ A. Kundani,The end of tolerance? Racism in 21st century Britain (London: Pluto Press, 2007), p. 184. 